\title{
Vigilar y castigar: crisis y disciplinamiento en la Iglesia argentina en los años setenta
}

\author{
Martín Obregón
}

Universidad Nacional de La Plata, Argentina

\begin{abstract}
Desde mediados de la década de 1960, el catolicismo argentino sufrió una aguda crisis interna, caracterizada por la radicalización de vastos sectores, tanto clericales como laicos, cuyos cuestionamientos fueron creciendo con el correr de los años. Desde los años setenta, la jerarquía eclesiástica estableció como objetivo central la reorganización de la Iglesia sobre bases conservadoras, lo que implicaba disciplinar a los sectores más radicalizados del campo católico. En este trabajo se analizan las características que adoptó dicho proceso en la teología, la liturgia y la pastoral durante los primeros años de la última dictadura militar.
\end{abstract}

PALABRAS CLAVE: Iglesia católica, radicalización, crisis, disciplinamiento, jerarquía eclesiástica.

Since the middle of the 60's, Catholicism experimented in Argentina a deep internal crisis: vast secular and ecclesiastic groups radicalized and their criticisms were growing in the following years. By the second middle of the 70's the ecclesiastical hierarchy fixed on to reorganize the Church on Conservative grounds and to discipline the more radical groups inside the Catholic ground. I attempt to analyze the theological, liturgical, and pastoral characteristics of this process during the first years of the latter Military Dictatorship.

KEYwords: Catholic Church, radicalism, crisis, discipline, ecclesiastical hierarchy.

\section{Introducción}

Las profundas transformaciones que tuvieron lugar en la Iglesia católica luego del Concilio Vaticano II y la Conferencia Latinoamericana de Medellín sumergieron a la institución eclesial en una aguda crisis interna. Uno de los aspectos más visibles de esa fractura en el interior del campo católico fue la radicalización de vastos sectores, tanto clericales como laicales, cuyos cuestionamientos a la jerarquía fueron creciendo desde comienzos de los años sesenta.

A mediados de los años setenta, cuando la dinámica de la crisis de la Iglesia se superpuso en la Argentina con la crisis política y social, la jerarquía católica profundizó el "giro a la derecha" que había iniciado a comien- 
zos de la década y estableció como objetivo central la reorganización de la Iglesia sobre bases claramente conservadoras, lo que implicaba disciplinar (y en no pocas ocasiones el aislamiento y la expulsión) los sectores católicos más radicalizados.

A lo largo de este artículo nos proponemos indagar las características que adoptó dicho proceso de disciplinamiento del campo católico en los ámbitos de la teología, la liturgia y la pastoral. Con respecto a las fuentes documentales vale señalar que nos hemos detenido, fundamentalmente, en el análisis de distintos documentos episcopales y del boletín de la Agencia Informativa Católica Argentina (AICA).

\section{La revolución llega a la Iglesia: el impacto del Concilio Vaticano II y la Conferencia de Medellín sobre el catolicismo argentino}

Las conclusiones del Concilio Vaticano II, con toda su impronta renovadora, minaron las bases sobre las que se había construido la Iglesia argentina, amplificando las tensiones que ya existían en el mundo católico entre aquellos que seguían aferrados a un horizonte tomista y que consideraban a la Iglesia como una "sociedad perfecta" y quienes pensaban que la institución eclesial debía adaptarse a los cambios ocurridos en el transcurso de las últimas décadas.

A decir verdad, los conflictos entre los sectores tradicionalistas y renovadores del catolicismo argentino se profundizaron luego de la finalización del Concilio, en 1965. Si bien los documentos conciliares exponían las orientaciones generales que debía seguir la Iglesia universal y los cambios que debían adoptarse, la forma y los tiempos en que se aplicarían las reformas en cada país quedaba en manos de los episcopados nacionales.

El segundo lustro de la década del '60 se ve enriquecido por episodios que ponen de manifiesto el conflicto en el interior del catolicismo y su Iglesia en torno a esta cuestión. En Mendoza, veintisiete sacerdotes renunciaron a sus cargos en 1965 y realizaron la primera "huelga de curas" con el objetivo de denunciar que en esa diócesis, administrada por monseñor Buteler, "no se vive el espíritu conciliar". ${ }^{1}$ En 1967, el obispo de Avellaneda, monseñor Jerónimo Podestá, presentó su renuncia, presionado

1 Mayol, A., Habegger, N. y Armada, A.: Los católicos posconciliares en la Argentina, Editorial Galerna, Buenos Aires, 1970, pág. 159. 
por el nuncio apostólico y el episcopado argentino. Podestá —un obispo que había dado muestras de su oposición al régimen militar encabezado por el general Onganía - había propiciado en su diócesis una "pastoral obrera y social" reuniendo a una cantidad importante de "curas obreros". Dos años antes del conflicto que lo enfrentó con la jerarquía, Podestá había mantenido en su diócesis a un sacerdote que había sido despedido de un establecimiento industrial por favorecer la organización de los trabajadores. ${ }^{2}$ En 1968 un acontecimiento similar tuvo lugar en Tucumán, donde un joven sacerdote encabezó algunas manifestaciones obreras. El gobernador militar de Tucumán lo acusó de "extremista", pero el Vicario Capitular de la arquidiócesis decidió apoyarlo, lo que impulsó a la jerarquía a reemplazarlo por monseñor Blas Conrero, un conservador que no dejaba lugar a dudas. ${ }^{3}$ Los conflictos intraeclesiales alcanzaron también a la diócesis de San Isidro, liderada por un obispo que había acompañado el proceso de renovación conciliar sospechoso de simpatizar con el grupo de "rebeldes" mendocinos. Monseñor Aguirre había aprobado la creación de un equipo sacerdotal orientado hacia el mundo del trabajo, pero la dinámica de ese grupo de sacerdotes - apoyados por un sector importante del laicado-derivó a los pocos meses en un enfrentamiento con el obispo y culminó con el alejamiento de los ocho curas obreros de la diócesis. ${ }^{4}$ En 1969 una treintena de sacerdotes de la diócesis de Rosario desafió la autoridad del arzobispo Bolatti, afirmando que "la jerarquía es ciega, sorda y muda a los signos de los tiempos".5

En todos estos episodios se verificaba el enfrentamiento entre la jerarquía católica y jóvenes sacerdotes identificados con el proceso de renovación conciliar, que cuestionaban los principios de autoridad y jerarquía y exigían una rápida implementación “del aggiornamiento pedido por Juan XXIII”. ${ }^{6}$

2 González, Lidia y García Conde, Luis: Monseñor Jerónimo Podestá: la revolución en la Iglesia, Ediciones del Instituto Histórico de la Ciudad de Buenos Aires, Buenos Aires, 2000. La de los "curas obreros" es una experiencia de origen francés que postulaba que los sacerdotes debían vivir de su propio trabajo y no del sueldo que recibían del Estado o de los servicios religiosos. El sacerdote que había sido defendido por monseñor Podestá se llamaba Francisco Huidobro y fue despedido de la fábrica INDUPAR.

3 Véase Mayol, Habegger y Armada: Los católicos..., pág. 183.

4 Véase Mayol, Habegger y Armada: Los católicos..., pág. 184 y 185.

5 Véase Mayol, Habegger y Armada: Los católicos..., pág. 186.

6 Véase Mayol, Habegger y Armada: Los católicos..., pág. 159. Para un desarrollo más extenso de estos conflictos intraeclesiales véase también el trabajo de Pontoriero, Gustavo: Sacerdotes para el Tercer Mundo: el fermento en la masa (1967-1976), Centro Editor de América Latina, Buenos Aires, 1991. 
Los planteos de las corrientes posconciliares eran bien concretos: una mayor apertura de la Iglesia con respecto a otros sectores de la sociedad y la posibilidad de un diálogo con otras corrientes de pensamiento, una renovación en el ámbito de la liturgia y de la exégesis de los textos sagrados, un compromiso activo con los sectores populares y una "pastoral de conjunto" que promoviera la participación en las diócesis de los sacerdotes y los laicos.

Los sectores renovadores tenían como referentes a un puñado de obispos que habían sido designados recientemente: monseñor Zazpe, monseñor Angelelli, monseñor Quarracino, monseñor Podestá y monseñor Devoto. Todos ellos impulsaron en sus diócesis procesos de renovación en el ámbito de los estudios teológicos y promovieron esquemas organizativos que favorecieron la participación de sacerdotes y laicos. A nivel del clero, una cantidad cada vez más importante de sacerdotes jóvenes que habían encontrado en la diócesis un espacio de articulación de diversas experiencias teológicas y pastorales constituyeron el sector más dinámico de la fracción renovadora. De allí surgirá el núcleo sacerdotal que organizará hacia fines de 1967 el Movimiento de Sacerdotes para el Tercer Mundo (MSTM), cuyas posiciones fueron mucho más allá de las que compartían todos los sectores partidarios de la "renovación conciliar". Por último, un nutrido conjunto de organizaciones laicales del apostolado católico que desarrollaban sus actividades en directo contacto con los sectores populares también militó activamente en favor de la implementación de reformas en la Iglesia. La Juventud Universitaria Católica (JUC), la Juventud Obrera Católica (JOC) y el Movimiento Rural de Acción Católica (MRAC) habían alcanzado un importante desarrollo desde comienzos de los años sesenta, radicalizando paulatinamente sus posiciones bajo la mirada cada vez más atenta de la jerarquía. ${ }^{7}$

Para la Iglesia argentina, edificada según los planos del integrismo católico y a partir de un vínculo muy estrecho con los poderes del Estado, la incorporación de las demandas de los sectores renovadores implicaba una transformación estructural a la que se opusieron con firmeza los secto-

7 Véase Touris, Claudia: "Ideas, actores y conflictos en el catolicismo argentino post-conciliar", ponencia presentada en las VIII Jornadas Interescuelas / Departamentos de Historia, Salta, Universidad Nacional de Salta, septiembre de 2001. Para del desarrollo de las corrientes posconciliares del catolicismo argentino véase también en trabajo de Moyano, Mercedes: "Organización popular y conciencia cristiana" en AA.VV.: 500 años de cristianismo en Argentina, Ediciones CEHILA-Centro Nueva Tierra, Buenos Aires, 1992. 
res tradicionalistas y conservadores, los que constituían una amplia mayoría en el seno del episcopado. ${ }^{8}$

En términos generales la cúpula de la Iglesia argentina seguía anclada en un horizonte preconciliar y hubiera preferido que las conclusiones del Vaticano II ratificaran el Sylabus de Pío IX condenando los "errores" del mundo moderno. ${ }^{9}$ Los sectores más tradicionalistas de la Iglesia, que seguían aferrados al ideal de la "nación católica", cerraron filas ante lo que consideraban una "desviación modernista" que ponía en peligro la existencia misma de la institución. La mayoritaria fracción conservadora, en tanto, parecía aceptar con resignación la introducción de unos pocos cambios, que debían ser graduales y supervisados estrictamente por la jerarquía.

Como ha señalado Loris Zanatta, desde 1965 temas como la ortodoxia doctrinaria y la relación de los sacerdotes con los obispos pasaron a estar en centro de las discusiones en el episcopado. En 1966 monseñor Tortolo - arzobispo de Paraná y figura arquetípica del integrismo católico- envió un informe a la Conferencia Episcopal advirtiendo al conjunto de los obispos que una organización como la JUC estaba dejando de lado el carácter "orgánico y jerárquico" de la Iglesia, inspirándose además en pensadores "no católicos". ${ }^{10}$ Para fines de ese mismo año, el arzobispo de Buenos Aires, cardenal Caggiano, censuró públicamente por medio de una carta pastoral una revista impulsada por un grupo de sacerdotes y laicos posconciliares. Para el máximo líder de la Iglesia nacional, la revista "Tierra Nueva" utilizaba un lenguaje "histórico y profético" y se caracterizaba por la falta de un conocimiento serio y profundo de la filosofía y teología católica", ${ }^{11}$

La crisis dentro del catolicismo argentino se profundizó en los últimos años de la década del sesenta, cuando una fracción importante de la renovación conciliar radicalizó de manera notable sus posiciones, vinculándose estrechamente con diversas organizaciones populares en el contexto de una

8 Los sectores tradicionalistas se nucleaban en torno a los jefes del Vicariato Castrense para las Fuerzas Armadas, monseñor Tortolo y monseñor Bonamín. Entre los principales exponentes de los tradicionalistas se encontraba también el sacerdote Julio Meinvielle y el rector de la Universidad Católica de La Plata, monseñor Octavio Derissi, verdaderos abanderados de la ortodoxia tomista. Los sectores conservadores eran ampliamente mayoritarios y se encolumnaban detrás de la figura del cardenal Antonio Caggiano, arzobispo de Buenos Aires.

9 Véase Mallimacci, Fortunato: "La continua crítica a la modernidad: análisis de los "vota" de los obispos argentinos al Concilio Vaticano II”, Sociedad y Religión, 10/11, junio de 1993.

10 Zanatta, Loris y Di Stéfano, Roberto: Historia de la Iglesia argentina, Grijalbo-Mondadori, Buenos Aires, 2000, pág. 507.

11 Véase Clarín, 9 de diciembre de 1966. Carta Pastoral del cardenal Antonio Caggiano. 
ascendente conflictividad social. En el plano eclesiástico, la II Conferencia del Episcopado Latinoamericano, que tuvo lugar en la ciudad de Medellín, Colombia, en 1968, dio lugar a un conjunto de interpretaciones que potenció la radicalización de los grupos católicos. Los documentos finales de Medellín propiciaban la "participación" de los cristianos en la "vida política de la nación" y la necesidad de "defender, según el mandato evangélico, los derechos de los pobres y oprimidos" y de "denunciar enérgicamente los abusos y las injustas consecuencias de las desigualdades excesivas entre ricos y pobres, entre poderosos y débiles, favoreciendo la integración". Los obispos latinoamericanos denunciaban también la violencia institucionalizada y expresaban que no debía extrañar "que nazca en América Latina la tentación de la violencia", en un pasaje que daría lugar a lecturas que justificaban su utilización por parte de los oprimidos. ${ }^{12}$

El Movimiento de Sacerdotes para el Tercer Mundo, que se había creado poco antes de la Conferencia de Medellín, constituyó sin dudas la experiencia más importante de esta radicalización del campo católico, llegando a aglutinar cerca de una décima parte del clero argentino. Como ha señalado José Pablo Martín, para el MSTM y para muchas organizaciones del apostolado católico la lectura de los documentos del magisterio y la interpretación del proceso socio-histórico en curso eran fenómenos que remitían el uno al otro, yuxtaponiendo la política con la religión. La "opción preferencial por los pobres" se traducía en una creciente participación en las luchas populares, en tanto que las críticas a la jerarquía se acentuaban a partir de su cercanía con el régimen del general Onganía. ${ }^{13}$

En el año 1970 se produjeron dos episodios que pusieron de manifiesto la fractura existente dentro de la institución eclesial: la publicación del libro La Iglesia clandestina ${ }^{14}$ una de las denuncias más virulentas contra el MSTM donde se postulaba la tesis de la "infiltración izquierdista en el seno de la Iglesia" y la difusión de vínculos entre algunos sacerdotes y la recientemente creada organización guerrillera Montoneros. ${ }^{15}$

12 II Conferencia General del Episcopado Latinoamericano, Documentos finales de Medellín, Ediciones Paulinas, Buenos Aires, 1970.

13 Véase Martín, José Pablo: Movimiento de Sacerdotes para el Tercer Mundo. Un debate argentino, Editorial Guadalupe / Ediciones Castañeda, Buenos Aires, 1992.

14 Sacheri, Carlos: La Iglesia clandestina, Ediciones del Cruzamante, Buenos Aires, 1970.

15 A los pocos días del secuestro del General Aramburu —operación que marcó la aparición pública de la organización Montoneros - se produjo la detención del padre Carbone a quien se vinculaba con el núcleo original de esa organización guerrillera. 
En un contexto caracterizado por una fuerte crisis interna y por el crecimiento de la "Iglesia del Pueblo" la respuesta de la jerarquía no se hizo esperar. La elección de uno de los críticos más implacables del MSTM, monseñor Tortolo, como presidente de la Conferencia Episcopal daba cuenta de la decisión de los vértices de la Iglesia de resolver el conflicto en clave conservadora y poner punto final a un proceso de radicalización que había llegado demasiado lejos. A lo largo de la primera mitad de la década del setenta la jerarquía avanzó en un proceso para disciplinar el campo católico que se profundizó luego del golpe de Estado del 24 de marzo de 1976.

\section{La Iglesia argentina entre el Concilio Vaticano II y la última dictadura militar: la teología, la liturgia y la pastoral como campo de batalla (1965-1976)}

Durante los dos lustros transcurridos desde la finalización del Concilio Vaticano II hasta el golpe militar que derrocó en marzo de 1976 al gobierno de Isabel Perón, la crisis interna de la Iglesia se expresó en diferentes planos: la teología, la liturgia y la pastoral se convirtieron en escenario de fuertes disputas.

En efecto, en la mayoría de los conflictos dentro de la Iglesia a los que hicimos referencia en el apartado anterior, los diversos sectores en pugna pretendieron justificar sus posiciones a partir de los textos sagrados y de los documentos del magisterio católico. El MSTM afirmaba que su accionar estaba en la línea del Concilio Vaticano II, de la encíclica Populorum Progressio, de la Conferencia de Medellín y del Documento de San Miguel del Episcopado argentino. Algunos teólogos muy influyentes dentro del movimiento como Lucio Gera y Rodríguez Melgarejo aprobaron con entusiasmo las conclusiones de Medellín, en las que encontraban una lectura "histórico-nacional" del Concilio Vaticano II, en tanto que los exponentes mayores del integrismo católico, como monseñor Octavio Derissi, colocaban en un plano secundario las cuestiones socio-económicas para reafirmar el "humanismo tradicional de la Iglesia" y recordar que "el reino de Dios comienza por los corazones" ${ }^{16}$ En términos generales puede afirmarse que amplios sectores de la jerarquía católica veían con preocupación la utilización de términos como "liberación", "dependencia" o "cambio de estructu-

16 Martín: Movimiento de Sacerdotes... 
ras" y que incluso sectores que habían alentado en la primera mitad de la década del sesenta los procesos de cambio - como los que expresaba la revista Criterio, dirigida por monseñor Jorge Mejía - se mostraban preocupados por lo que consideraban una lectura abusiva de los documentos del magisterio católico. ${ }^{17}$

Un segundo aspecto donde se hacían visibles las diferencias en el interior del mundo católico tenía que ver con las celebraciones litúrgicas. En este sentido, los sectores más radicalizados de la renovación conciliar no dejaban de denunciar el vaciamiento que experimentaba el culto y la necesidad de que "lo pronunciado en la celebración fuera puesto en relación con la vida de los que celebraban". ${ }^{18}$ La protesta encabeza por los sacerdotes tercermundistas entre los días 18 y 24 de diciembre de 1968, que incluyó jornadas de oración y reflexión, ayunos y hasta la supresión de las misas de Nochebuena en algunas parroquias, era muy clara al respecto, y sostenía que la Navidad se había transformado en una "fiesta folklórica", "un derroche de lujo", "una participación superficial y fácil de la eucaristía de medianoche". ${ }^{19}$ Para el MSTM — que como vimos hacía una lectura de los evangelios desde una perspectiva histórico-sociológica - la función del sacerdote debía ser fundamentalmente profética, es decir, orientada a la liberación de su pueblo. Los sectores más progresistas del catolicismo posconciliar se oponían a un culto que no fuera coherente con esa finalidad y lo denunciaban como mero ritualismo. De alguna manera esa concepción estaba presente en el obispo de Neuquén, monseñor Jaime de Nevares, cuando en 1971 se negó a bendecir una capilla que había levantado dentro de su diócesis una empresa constructora que mantenía un conflicto con sus trabajadores..$^{20} \mathrm{La}$ intervención en ese mismo episodio del segundo jefe del vicariato castrense, monseñor Bonamín, que finalmente bendijo el templo en cuestión, ilustra a su vez la concepción opuesta: la que entendía el culto como una instancia válida en sí misma, que debía ser garantizada más allá de la conducta de los fieles. ${ }^{21}$

Por último, la fractura dentro del catolicismo argentino se puso de manifiesto en el ámbito de la pastoral. Como demostraba la experiencia de

17 Martín: Movimiento de Sacerdotes..., pág. 81.

18 Martín: Movimiento de Sacerdotes..., pág.121.

19 Véase Pontoriero: Sacerdotes para el..., pág. 44. pág. 61 y ss.

20 De Nevares, Jaime: La verdad nos hará libres, Nueva Tierra, Buenos Aires, 1994,

21 Ibídem, pág. 76. 
los "curas obreros" y otras similares como la de los "curas villeros" en la Capital Federal o la de las ligas agrarias del litoral del país, era la pastoral popular enmarcada en la "opción preferencial por los pobres" el terreno donde se verificaba con mayor nitidez la radicalización de los militantes católicos y donde se producían choques cada vez más frecuentes entre los sacerdotes y laicos comprometidos y la jerarquía de la Iglesia.

Si para los católicos progresistas era evidente que la función de la Iglesia era la de intervenir en el proceso histórico a favor de los sectores más desposeídos, los grupos conservadores y tradicionalistas respondieron acentuando de las cuestiones espirituales por sobre las materiales, al plantear la distinción entre el reino terrenal y el reino de los cielos y acusando frecuentemente a los católicos comprometidos con una pastoral popular de tener vínculos con el marxismo.

\section{La Iglesia argentina bajo el "Proceso": de la crisis interna al "disciplinamiento"}

Durante los primeros años del "Proceso" una de las preocupaciones centrales del episcopado católico giró en torno a la ortodoxia doctrinaria, que buscaba, precisamente, evitar aquellas "interpretaciones abusivas" de las que hablaba monseñor Mejía. Por ello se hacía necesario para la cúpula de la Iglesia ejercer una fuerte supervisión y control sobre todas aquellas publicaciones y medios de difusión que abordaran cuestiones doctrinarias y teológicas, como así también sobre los grupos y las instituciones que llevaban a cabo dichas tareas. En este terreno, las polémicas y los debates tuvieron lugar también en el seno del episcopado, que no pudo ocultar sus diferencias en ocasión de la discusión sobre la llamada "Biblia Latinoamericana".

Un segundo objetivo de la cúpula eclesiástica consistió en uniformizar las prácticas litúrgicas en un sentido amplio, que iba desde la vestimenta de los sacerdotes hasta la música y las letras de las canciones que se interpretaban en las ceremonias religiosas. Además, la jerarquía católica puso especial énfasis al momento de advertir las "desviaciones" que suponían ciertas prácticas bastante generalizadas entre la feligresía, tales como el culto o la adoración de figuras que no eran reconocidas por la Iglesia.

Por último, la política disciplinaria que llevaron adelante los sectores mayoritarios de la jerarquía católica tuvo sus consecuencias en el plano de 
la pastoral. Como ya se ha señalado, uno de los rasgos que caracterizaba a las corrientes progresistas del catolicismo era su vinculación con diferentes sectores de la sociedad, especialmente con los más desposeídos, en el marco de la "opción preferencial por los pobres". Por eso mismo, los trabajos territoriales que los integrantes de la "Iglesia del Pueblo" desarrollaban en barrios obreros, villas de emergencia, comunidades indígenas y campesinas eran seguidos no sin desconfianza por una parte importante del episcopado, sobre todo por los sectores más tradicionalistas, que veían en esas prácticas una subordinación de los aspectos espirituales a los materiales. Luego del golpe, en el marco de una verdadera "caza de brujas" desatada por los militares, donde se acentuó aún más la tendencia a vincular a estos grupos con el marxismo y con la "subversión", la jerarquía desalentó ese tipo de trabajos. De esa manera, al tiempo que se aislaba y controlaba a los sectores más dinámicos, se privilegiaba un tipo de pastoral que apuntaba a recuperar posiciones en el terreno de las ideas y de la cultura, como así también en el plano de la moral sexual y familiar, acompañando la cruzada que se iniciaba contra lo que muchos obispos denominaban "desacralización". ${ }^{22}$ Esta opción implicó, al menos durante los dos primeros años del "Proceso", una acentuación de los aspectos espirituales por sobre los histórico-temporales y se tradujo, en algunas diócesis más que en otras, en una Iglesia escasamente vinculada al resto de los actores sociales.

\section{El restablecimiento de la ortodoxia doctrinaria}

Como hemos afirmado a lo largo del presente artículo, uno de los escenarios más importantes de la batalla ideológica que dividió al catolicismo desde los tiempos del Concilio fue la interpretación de los textos sagrados y del magisterio de la Iglesia universal. En efecto, los debates teológicos y doctrinarios adquirieron a lo largo de esos años una dimensión central, ya que era precisamente en las diferentes interpretaciones de ese conjunto de textos y de documentos donde encontraban sus fundamentos las diferentes prácticas que cada uno de los sectores en pugna desplegaba en el plano de la liturgia y de la pastoral. Para la jerarquía católica estaba

22 En este sentido no deja de ser significativo que el programa matrimonio y familia fuese definido por el episcopado como la prioridad pastoral para el año 1976. 
claro que no se podía dejar atrás la crisis interna si no se zanjaban esas disputas mediante el restablecimiento de una rigurosa ortodoxia doctrinaria. ${ }^{23}$

Más allá de que en algunas ocasiones los jefes de la Iglesia argentina amonestaron a los grupos que ponían en peligro la ortodoxia doctrinaria con planteos extremadamente tradicionalistas, lo cierto es que la política de encauzamiento estuvo dirigida a todos aquellos grupos que habían interpretado los documentos eclesiásticos y los textos sagrados desde una perspectiva "progresista", como por ejemplo los sacerdotes reunidos en el MSTM. En la coyuntura restauradora de mediados de los años setenta la jerarquía intentó supervisar y controlar, por un lado, todas las publicaciones y medios de comunicación que se dedicaban a la difusión de temas vinculados a la doctrina de la Iglesia y, por otro lado, a todos los grupos e instituciones católicas que realizaban esas tareas.

En efecto, la cuestión de la ortodoxia doctrinaria, enfocada particularmente desde el punto de vista de la enseñanza en los colegios católicos, formó parte del temario de la primera asamblea episcopal del año 1976, y durante ese año (y los siguientes) se registró, en distintas diócesis del país, un conjunto de episodios en los que las más altas autoridades eclesiásticas impugnaron o desautorizaron abiertamente a grupos católicos que, según su criterio, se estaban alejando de los principios doctrinarios del magisterio de la Iglesia.

En mayo de 1976, por ejemplo, el arzobispado de Buenos Aires aclaraba, a través de un comunicado, que la entidad denominada Difusora Mariana Argentina "no tiene reconocimiento ni aprobación de la autoridad eclesiástica de esta arquidiócesis", afirmando también que dicha institución "da lugar a serias objeciones de parte de la doctrina católica, pretendiendo difundir ideas supuestamente ortodoxas que engendran confusión entre los fieles". ${ }^{24}$ Para evitar esas desviaciones, el cardenal Aramburu emitió una circular recordando las normas vigentes en materia de censura previa de publicaciones vinculadas a "la religión y las buenas costumbres", subrayando que en todos los casos se debía contar con la correspondiente autorización del obispo y señalando que "sin la competente autorización eclesiástica" no se podían utilizar en los institutos de enseñanza libros concernientes a la Sagrada Escritura, la Sagrada Teología o el Derecho Canónico". ${ }^{25}$

23 Zanatta: Historia de la Iglesia...

24 Agencia Informativa Católica Argentina (en adelante AICA), 13 de mayo de 1976.

25 AICA, 24 de junio de 1976. 
Unos meses más tarde, también en el ámbito de la arquidiócesis primada, fueron desautorizados públicamente dos grupos denominados "Cristianos para la Liberación" y "Comunidades parroquiales de Buenos Aires y Gran Buenos Aires", los que según un comunicado dado a conocer por el arzobispado "no tienen vinculación con esta curia eclesiástica". ${ }^{26}$

Episodios similares se registraron también en el interior del país. En San Luis, donde el obispo Rodolfo Laise demostraría un particular empeño en la preservación de la ortodoxia religiosa, se desautorizó en todo el territorio de la diócesis una revista editada por misioneros franciscanos para toda América Latina. Concretamente, se acusaba a "El mensajero de San Antonio" de haber caído en desviaciones como el "antropocentrismo", el "temporalismo" y el "evangelismo". Para monseñor Laise, la publicación en cuestión adoptaba, tanto en las temáticas como en el contenido de sus artículos, "una visión casi exclusivamente horizontalista y parcializante del mensaje de la Iglesia", y vislumbraba en ella "una posición simpatizante con la ideología y los métodos del marxismo". ${ }^{27}$

Se trataba, por lo general, de episodios que enfrentaban verticalmente a la jerarquía con grupos de sacerdotes y laicos que militaban en la corriente posconciliar. Sin embargo, los debates doctrinarios y teológicos se desarrollaron también en un nivel horizontal, es decir, entre los propios obispos, como lo prueba la discusión que tuvo lugar en el seno del episcopado durante la segunda mitad de 1976 en torno a una edición de la Biblia editada por Ediciones Paulinas y Ediciones del Verbo Divino en el año 1974.

La polémica se originó a raíz de una declaración del arzobispo de San Juan, que repudió la aparición de la Biblia Latinoamericana y ordenó que "en ningún establecimiento o asociación católica de la provincia se tenga en modo alguno el volumen señalado", ya que en él se hacía una "exaltación del marxismo". ${ }^{28}$ Para monseñor Sansierra, dicha Biblia se encuadraba "dentro del plan establecido por el comunismo internacional cuya doctrina es extranjera, atea, perversa y sanguinaria, para la subversión y luego esclavitud de nuestro continente". ${ }^{29}$ Monseñor Sansierra aclaraba un poco más sus conceptos señalando que "desde hace muchos años" el comunismo había adoptado la estrategia de "ganar a los pueblos latinoamericanos

\footnotetext{
26 AICA, 22 de julio de 1976.

27 AICA, 15 de julio de 1976.

28 AICA, 23 de septiembre de 1976.

29 Ibídem.
} 
no bajo el signo de la hoz y el martillo, sino bajo el signo de la cruz". ${ }^{30}$ Pocos días después monseñor Tortolo firmó un comunicado prohibiendo la circulación en la diócesis de Paraná de la Biblia Latinoamericana, debido a que bastaba "una simple mirada" para que el pueblo fiel "advierta escandalizado que no pocas láminas y explicaciones anexas son tendenciosas". ${ }^{31} \mathrm{El}$ tema, fuertemente publicitado por algunos medios de prensa vinculados al gobierno militar, puso de manifiesto las diferencias existentes dentro de la jerarquía católica. Más aún cuando se conoció la posición del obispo de Neuquén, monseñor Jaime de Nevares, que luego de afirmar que las notas cuestionadas ponían al descubierto "muchas cosas que molestan" recomendaba "calurosamente" la lectura, en su diócesis, de la Biblia en cuestión. ${ }^{32}$

Desde los sectores más moderados de la jerarquía, que advertían que la cuestión además de volver a dividir aguas en el episcopado exponía públicamente las profundas diferencias que existían en la Iglesia argentina, se trató de bajar los decibeles de la discusión y esperar a que el tema se resolviese en la comisión de Teología de la Conferencia Episcopal.

Uno de los que intentó poner paños tibios en medio de la polémica fue el arzobispo de Santa Fe, monseñor Zazpe, al pronunciarse en contra de las acusaciones "rotundas" y "universales" que "empañaban la imagen de todos los episcopados de América Latina", los que, en el caso de la Biblia Latinoamericana, habían "permitido su difusión durante cinco años sin advertir un peligro tan tremendo y evidente". ${ }^{33}$

Los alcances de la polémica llevaron a que la cuestión fuera objeto de tratamiento durante la segunda Asamblea Plenaria del episcopado, al término de la cual se dio a conocer un documento en el que se intentaba unificar las diferentes posiciones. ${ }^{34}$ La jerarquía católica buscaba, por un lado, poner límites a los avances de los sectores más tradicionalistas del catolicismo y a ciertos sectores civiles y militares que habían convertido el tema en una verdadera cruzada. Además hacía referencia a la "publicidad inusitada" que había alcanzado el tema, al tiempo que advertía que "la interpretación auténtica de la Sagrada Escritura en la Iglesia es derecho exclusivo del magisterio jerárquico, y ningún poder, cualquiera sea su motivación,

30 Ibídem.

31 AICA, 7 de octubre de 1976.

32 La Nación, 12 de octubre de 1976.

33 AICA, 7 de octubre de 1976.

34 "Declaración de la Conferencia Episcopal Argentina sobre la llamada Biblia Latinoamericana", Documentos finales..., pág. 301-303. 
puede interferir en esta fundamental función de los obispos". ${ }^{35}$ No deja de ser significativo, además, que la jerarquía considerase necesario en ese documento condenar "con firmeza" tanto "la ideología" como "la praxis" del marxismo, lo que daba cuenta de la magnitud de la ola de acusaciones y sospechas que afectaban a la institución.

La forma en que se saldó la discusión en torno a la llamada Biblia Latinoamericana confirma de alguna manera que el objetivo central de la cúpula de la Iglesia pasaba por asegurar su cohesión institucional a partir de una rígida supervisión, en clave fuertemente conservadora, de la ortodoxia doctrinaria. Para ello era condición necesaria, pero no suficiente, terminar de disciplinar a aquellos sectores que habían hecho una interpretación "temporalista" del magisterio de la Iglesia; se trataba también, y cada vez más, de dejar paulatinamente de lado las posiciones del tradicionalismo más exacerbado. ${ }^{36}$

Era por ello que la respuesta episcopal intentaba acercar las distintas posiciones quitando legitimidad a las pretensiones más extremas. En cuanto al texto y traducción de esa edición de la Biblia, el episcopado consideró que era "sustancialmente fiel", aunque formuló objeciones a las introducciones, notas e ilustraciones que acompañaban al texto, elementos que hacían necesaria una "revisión y complementación". El episcopado resolvió a tal efecto promover un suplemento especial para las ediciones de la Biblia Latinoamericana que circularan en la Argentina. De esa manera era posible "salvar sus muchos aspectos positivos" y superar aquellos que eran, por lo menos, "discutibles". ${ }^{37}$

\section{La supervisión de las prácticas litúrgicas}

El segundo aspecto en el que la jerarquía avanzó en su proyecto de reorganizar y uniformizar a la totalidad del campo católico fue, desde luego, el litúrgico, donde se venían manifestando fuertes tensiones. En términos generales, esta estrategia de disciplina se desarrolló en dos niveles diferentes: por un lado, se dirigió a los sectores subordinados de la institución

35 Ibídem.

36 Véase Zanatta, Loris: "Religión, nación y derechos humanos. El caso argentino en perspectiva histórica”, Revista de Ciencias Sociales, 7/8, Quilmes, Universidad Nacional de Quilmes, 1998.

37 Ibídem. 
eclesial (sacerdotes, religiosos y organizaciones del apostolado católico) y, por otro, a la feligresía en su conjunto.

Con respecto a las disposiciones que afectaban a los sacerdotes y a los religiosos, es posible advertir una fuerte preocupación de la jerarquía católica por la imagen de éstos, en especial en lo referido al uso del hábito religioso. En este sentido, resulta por demás significativo que a pocos días del golpe la comisión permanente del episcopado se haya visto precisada de emitir un documento en el que recordaba que "el hábito de los eclesiásticos y personas que profesan el estado religioso debe ser simple, modesto, pobre y decente, de tal modo que constituyese siempre un signo evidente para los fieles, de la condición sacerdotal o consagración religiosa, tanto de varones como de mujeres". ${ }^{38}$ Luego de lamentar que dichos valores hayan sido "muy descuidados e impugnados incluso bajo pretextos doctrinales o pastorales", las autoridades de la Iglesia terminaban advirtiendo que "no está permitido ni a los sacerdotes del clero diocesano ni a los religiosos vestir de tal modo que no se distingan de los laicos, sino que el mismo vestido debe identificarlos, en todas partes, como sacerdotes o religiosos". 39

Las directivas de la comisión permanente fueron reforzadas, en algunas diócesis, mediante notas y documentos firmados por los obispos. Así, por ejemplo, en la arquidiócesis primada el cardenal Aramburu urgía "maternal pero firmemente" a los sacerdotes y a las comunidades religiosas bajo su jurisdicción "el uso correcto del hábito religioso" ante la evidencia de que en algunas comunidades éste se había comenzado a dejar de lado, adoptándose "un vestido más civil". ${ }^{40}$ También en Rosario, el arzobispo Bolatti dio a conocer un documento sobre la conducta y la vestimenta de los religiosos, donde se recordaba, entre otras cosas, que "el hábito reglamentario era la sotana (o el hábito en las monjas) o el clergyman"; que "los miembros del clero no deben presentarse en público con camisas y cuellos de uso civil, abundante cabellera o largas patillas a imitación de la moda seglar" y que "las confesiones a mujeres deben tomarse en los confesionarios con rejilla y cortinilla que impida la visión entre penitente y confesor". El documento de monseñor Bolatti advertía, por último, que "el quebrantamiento reiterado de estas disposiciones será objeto de sanción o

38 "Declaración de la comisión permanente de la Conferencia Episcopal Argentina sobre el hábito eclesiástico", Documentos finales..., pág. 275.

39 Ibídem.

40 AICA, 29 de abril de 1976. 
advertencia canónica, reclamándose el decoro del estado clerical y dando testimonio de su consagración superior". ${ }^{41}$

La preocupación de los vértices de la Iglesia argentina por uniformizar y supervisar estrictamente el conjunto de las prácticas litúrgicas alcanzó también a la música y a los cancioneros que se utilizaban durante las ceremonias religiosas. En este sentido, cabe señalar que en los sectores más tradicionalistas y conservadores de la jerarquía católica estaba muy presente la idea de que la "infiltración marxista" en el seno de la Iglesia era un fenómeno que podía detectarse en casi todos los ámbitos de la vida religiosa, en lo que constituía un paralelismo con la caracterización que hacía el régimen militar de la "subversión" como un fenómeno global.

Es en ese contexto defensivo que los sacerdotes de la diócesis de San Luis advertían, en octubre de 1976, que "frente al agudo proceso de desacralización que atenta actualmente contra la música y el canto sagrados y que se manifiesta tanto en la profanidad de las melodías como en el contenido de las letras (triviales, horizontalistas o subversivas) advertimos la importancia de tener bien en claro la naturaleza y finalidad del canto sacro." ${ }^{22}$ Para la misma época, la arquidiócesis de Rosario tomaba una determinación similar ante "la proliferación de cantos y loas de lo más diversos y que no siempre se ajustan a las normas y criterios vigentes" y prohibía expresamente las letras de protesta o de cualquier otro tipo que "de manera abierta o solapada, directa o indirectamente, inciten a la violencia, a la rebelión, al odio y a la lucha de clases". ${ }^{43}$

En la capital, la repercusión que comenzó a tener este tema motivó una aclaración sobre los cantos litúrgicos de parte del Consejo Litúrgico Arquidiocesano. En dicho documento, el titular de ese organismo, el presbítero Alberto Balsa, reconocía que, "pese a los esfuerzos realizados no siempre los criterios adoptados en la práctica han correspondido a una correcta interpretación de los documentos", debido a lo cual, en algunos casos, "la sana creatividad ha sido mal interpretada", dando lugar a "la divulgación de equívocos" ${ }^{44}$ Eran esos mismos equívocos los que llevaban a la arquidiócesis primada a delimitar con precisión cuales eran los cánticos que podían entonarse en las celebraciones litúrgicas y para-litúrgicas, haciendo expresa mención de los cancioneros en que aquellos se encontraban.

\footnotetext{
41 La Prensa, 12 de abril de 1976.

42 AICA, 14 de octubre de 1976.

43 AICA, 28 de octubre de 1976.

44 AICA, 14 de octubre de 1976.
} 
Al mismo tiempo que avanzaba en aquellas cuestiones, el episcopado dirigía también sus esfuerzos a controlar estrictamente la manera en que se manifestaba la fe religiosa del pueblo católico. En particular, lo que estaba siendo objeto de preocupación era la forma que asumía en ocasiones la religiosidad popular, que al rendir culto a figuras o a imágenes que la Iglesia no había reconocido oficialmente, cobraba una autonomía que era percibida como muy peligrosa por la jerarquía. No era casual, en este sentido, que a los pocos días de dar a conocer el documento sobre el hábito religioso, los obispos argentinos emitiesen una declaración titulada "sobre el culto de los santos y de las almas del purgatorio", advirtiendo acerca de los abusos que tenían lugar en ese terreno: "algunas veces la religiosidad popular es desvirtuada por la superstición y un indebido afán de lucro, alentado por un engañoso turismo y sus derivados". ${ }^{45}$

El caso de la adoración a la llamada "Difunta Correa", al que el episcopado se refiere de manera explícita en el citado documento, constituye un ejemplo significativo de las políticas adoptadas por la jerarquía tendientes a preservar la ortodoxia de la Iglesia: "Hay casos concretos en que, sin que conste históricamente su existencia y al margen de la autoridad eclesiástica, se rinde culto a determinadas personas. Tal es el caso de la llamada Difunta Correa, cuyo culto ilegítimo se ha extendido desde Vallecito, en San Juan, a lo largo y a lo ancho de la República, a través de templetes, ermitas y profusión de estampas e imágenes, con no pocas derivaciones supersticiosas". La Conferencia Episcopal Argentina, luego de declarar "ilegítimo y reprobable" dicho culto pedía a los "verdaderos católicos" que se abstengan de practicarlo. ${ }^{46}$

En ese caso particular, la reacción del gobierno de Tucumán, que entre otras medidas tendientes a "erradicar" dicho culto de la provincia ordenó la limpieza de los lugares públicos en los que se habían construido nichos para su veneración, no deja de ser significativa. Se trataba de una nueva demostración por parte de las autoridades militares del empeño que estaban dispuestas a poner para salvaguardar la ortodoxia de la doctrina católica, ya que cualquier desviación respecto de ella misma atentaba contra los valores fundantes de la argentinidad. ¿O no habían comprobado acaso los militares tucumanos que "los nichos construidos para su veneración han

45 "Declaración de la Conferencia Episcopal Argentina sobre el culto de los santos y de las almas del purgatorio", Documentos finales..., pág. 276-278.

46 Ibídem. 
sido aprovechados para la propaganda subversiva"? ${ }^{47}$ Años más tarde, cuando las autoridades militares de San Luis adoptaron la misma medida, la felicitación del obispo no se hizo esperar: "En esta provincia, los gobernantes saben cumplir la ley y actuar dentro del derecho", señaló monseñor Laise. ${ }^{48}$

A comienzos de 1979, la III Conferencia General del Episcopado Latinoamericano, que tuvo lugar en Puebla, situaría a la religiosidad popular en un lugar central dentro de la estrategia de expansión del catolicismo en el subcontinente. En la Argentina, una jerarquía que estaba dando los últimos pasos en la tarea de reorganizar a la Iglesia sobre bases decididamente conservadoras podía — una vez restablecida la ortodoxia en el plano de la liturgia y el culto- encontrar en el fomento de la religiosidad popular una manera de imprimirle mayor dinamismo y arraigo social al catolicismo en su conjunto.

\section{De la pastoral popular al reino de los cielos}

Uno de los rasgos centrales que adquirió el avance de los sectores tradicionalistas y conservadores en el campo doctrinario fue, sin lugar a dudas, la acentuación de una línea cada vez más "espiritualista", que buscaba desacreditar la lectura que las corrientes "progresistas" de la Iglesia realizaban desde una perspectiva histórico-social.

Para el obispo de San Rafael, León Kruk, era inadmisible que Cristo "hubiese venido nada más que para enseñarnos a arreglar nuestros asuntos y cuestiones terrenas", ya que "las desigualdades, las injusticias, las opresiones, el sojuzgamiento entre los hombres eran efecto de una sola causa: el pecado" ${ }^{49}$ En la misma dirección, el obispo de Mar del Plata, monseñor Rómulo García, expresaba que no eran "las estructuras socio-políticas y económicas en sí ni las revoluciones de diverso tipo las que nos harán gustar los frutos de un orden nuevo". Ese orden nuevo debía surgir, para monseñor García, de "la propia interioridad del hombre", una interioridad que pasaba más por "ser justos que por pedir justicia" y por "ser libres de los vicios que nos aprisionan más que por proclamar la libertad". ${ }^{50}$

47 AICA, 1 de julio de 1976.

48 La Nación, 29 de marzo de 1982.

49 AICA, 6 de mayo de 1976.

50 AICA, 29 de abril de 1976. 
En paralelo a este proceso de refuerzo de los aspectos espirituales por sobre los materiales — que implicaba un despegue radical con respecto a las posiciones que el mismo episcopado había suscripto en el Documento de San Miguel, en 1969 - se desarrollaba otro, que tendía a vincular con el accionar de la "subversión" a todas las iniciativas pastorales que privilegiaban el trabajo con los sectores más humildes de la población.

Esa estrategia, promovida tanto por los militares como por los sectores más tradicionalistas del catolicismo argentino, había sido denunciada públicamente por monseñor Angelelli, que señalaba que lo que se buscaba era "separar a la Iglesia del pueblo; separar a los pastores — sean ellos obispos o sacerdotes - de sus comunidades; se busca separar a los sacerdotes entre sí; sembrar en el pueblo y en las mismas comunidades religiosas la 'sospecha', la 'desconfianza' de sus hermanos; se busca separar a las diócesis argentinas; se busca contraponer la Iglesia de Pío XII a la de Juan XXIII o Pablo VI, haciendo aparecer a la de Pío XII como fiel y a la de Juan XIII y Pablo VI como infiel; se busca separar a los laicos militantes y apostólicos 'peligrosos'; se busca obstaculizar la misión evangelizadora de la Iglesia porque se cree que prepara la 'subversión' en el pueblo". ${ }^{.1}$

Las palabras de monseñor Angelelli — que se convertiría en víctima de esa misma estrategia que denunciaba - fueron certificadas por los hechos. En el mes de agosto de 1976 se produjo un acontecimiento que, aunque en apariencia anecdótico, puso de relieve la fuerte campaña de ciertos sectores de la ultraderecha católica, que abonaban la tesis de la infiltración marxista dentro de la Iglesia. En esa ocasión, una reunión de obispos, sacerdotes y laicos de diferentes países que tuvo lugar en Ecuador fue interrumpida violentamente por las Fuerzas Armadas de ese país y los participantes del evento, entre los que se encontraba monseñor Zazpe, fueron detenidos por unas horas, hasta que abandonaron el lugar. El encuentro, que según el gobierno ecuatoriano tenía características "subversivas", había sido organizado por el obispo de Riobamba, monseñor Leónidas Proaño, que desarrollaba una intensa actividad pastoral entre los indígenas del lugar y tenía como objetivo, según la carta que los obispos escribieron a Pablo VI desde su lugar de detención, "reflexionar sobre problemas relacionados con la evangelización de nuestras respectivas diócesis en el actual contexto histórico de las Américas". ${ }^{52}$

51 AICA, $1^{\circ}$ de abril de 1976.

52 Mejía, Jorge: "El episodio de Ecuador", Criterio, 1747, 9 de septiembre de 1976. 
De regreso a la Argentina, y ante la nueva ofensiva de quienes acusaban a ciertos sectores de la Iglesia de complicidad con el marxismo, monseñor Zazpe definía la posición de los sectores moderados con relación a este tema. El arzobispo de Santa Fe se preocupaba por dejar en claro la distancia que separaba a la Iglesia del comunismo, una ideología a la que calificaba como "inhumana" y "radicalmente opresora", pero recalcaba al mismo tiempo el deber de la Iglesia de "proyectar el evangelio" a todos los sectores de la vida humana..$^{53}$ Para monseñor Zazpe, esa misión de la Iglesia incluía, desde luego, la denuncia de las "injusticias sociales" y la defensa de los intentos de "cambios legítimos" en la situación social, pero fundamentalmente la denuncia de "toda violación que bajo cualquier pretexto atente contra los derechos fundamentales de la vida humana".$^{54}$ El tema de los derechos humanos se ubicaba claramente, a mediados de 1976, en el centro de las preocupaciones eclesiásticas, y monseñor Zazpe advertía los intentos del régimen militar de acusar, a quienes se dedicaran a la defensa de tales derechos, de complicidad con el marxismo o con organizaciones subversivas. Por eso señalaba que la Iglesia no desconocía "la consigna de desprestigiar con acusaciones de miserable inmoralidad a los obispos, sacerdotes y laicos que se destaquen en el campo de la defensa de ciertos derechos humanos", a pesar de lo cual la actitud de los católicos no podía transformarse en "silencio cobarde frente a situaciones que claman al cielo". ${ }^{55}$ Si la Iglesia "defiende con uñas y dientes la vida humana concebida en el seno materno", proseguía monseñor Zazpe, "deberá defender con igual intensidad la vida humana nacida, y no por connivencias marxistas sino porque el Evangelio grita en el Sermón de la Montaña que toda vida humana vale más que el universo, que el dinero, la comida, el vestido o cualquier ideología". ${ }^{56}$ Para el arzobispo de Santa Fe, la Iglesia estaba siendo "repudiada a la vez por el marxismo y por ciertos antimarxismos de dudosa finalidad". ${ }^{57}$

Una posición similar sostendría Jorge Mejía desde las páginas de Criterio, que al intentar establecer las razones del episodio de Ecuador, criticaba la "convicción, que hoy comienza a estar difundida en varios

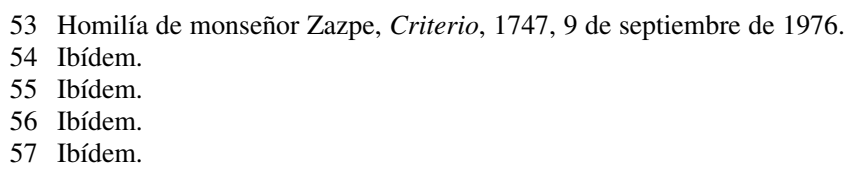


países, el nuestro entre otros, de que la Iglesia está infiltrada de marxismo, y que por consiguiente, ciertas reuniones, actos, o procederes suyos o de sus miembros, constituyen una amenaza a la seguridad del Estado". ${ }^{58}$ Para el director de la tradicional publicación católica, la Iglesia se encontraba "asediada" tanto por la izquierda como por la derecha.

A lo que se asistía era, a decir verdad, a una fuerte ofensiva de los sectores tradicionalistas, ya que los sectores "progresistas" del campo católico se encontraban en pleno proceso de desarticulación, como consecuencia de la inusitada represión de que fueron objeto por parte del terror estatal y de las fuertes políticas disciplinadoras de la jerarquía católica. En la práctica, los sectores mayoritarios de la jerarquía aprovecharon esa atmósfera de sospechas y acusaciones para desalentar todos aquellos trabajos e iniciativas pastorales que, por un lado ponían a la Iglesia en contacto con los diversos actores sociales que habían protagonizado la protesta social en la Argentina y que, por otro lado, habían sido llevados adelante por los sectores más radicalizados del campo católico. La relación entre el Movimiento de Sacerdotes para el Tercer Mundo, por ejemplo, y una línea de pastoral popular que privilegiaba la relación con los sectores más desposeídos era evidente, por lo que muchas figuras de la cúpula eclesiástica sostenían la necesidad de limitar y supervisar estrictamente ese tipo de prácticas. Durante los dos primeros años del "Proceso" las iniciativas pastorales que se ubicaban en la línea de la "opción preferencial por los pobres" pudieron seguir desarrollándose no sin dificultades - en unas pocas diócesis (como las de Neuquén o Viedma) y constituyeron (como en el caso del equipo arquidiocesano de villas de emergencia del arzobispado de Buenos Aires) una fuente de conflictos permanentes con la jerarquía eclesiástica y con las autoridades militares.

Lo que prevalece, en cambio, es un tipo de pastoral que, impulsada por el episcopado en su conjunto, tiene por objeto enfrentar lo que se percibía como el avance de un proceso de secularización (o de "desacralización" en palabras de los obispos), ya que se caracterizaría por un marcado conservadurismo social y cultural. La prioridad pastoral definida por el episcopado para todo el año 1976, el programa "matrimonio y familia", se enmarca en esa estrategia defensiva y conservadora.

58 Mejía, Jorge: "El episodio de Ecuador", Criterio, № 1747, 9 de septiembre de 1976. 


\section{Consideraciones finales}

Luego del golpe de Estado del 24 de marzo de 1976, en un contexto caracterizado por el "disciplinamiento" social que implementó la última dictadura militar mediante el terrorismo de Estado, los sectores mayoritarios de la jerarquía católica argentina profundizaron el giro conservador que se había iniciado a comienzos de la década del setenta.

El objetivo central del episcopado católico consistió en restaurar la unidad institucional y superar la crisis interna que azotaba a la Iglesia desde los tiempos del Concilio Vaticano II.

Para ello procuró restablecer la ortodoxia doctrinaria, uniformizar las prácticas litúrgicas y desalentar un tipo de pastoral popular que había favorecido el desarrollo de la "Iglesia del Pueblo", cuyo accionar había generado honda preocupación entre los obispos.

Hacia fines de los años setenta y comienzos de los ochenta, en el contexto de los cambios operados tanto en el ámbito de la política y la sociedad en nuestro país como a nivel de la Iglesia universal, las máximas figuras del catolicismo argentino darían paso a una estrategia diferente: una vez superada la crisis interna a partir de la subordinación y de disciplinar a los sectores "progresistas", se planteaba, para la Iglesia, el desafío de avanzar en la recomposición institucional a partir de una mayor inserción en el plano social. En este sentido, cada vez fueron más (y cada vez más influyentes) los que advertían la necesidad de incorporar a la vida de la Iglesia, ahora despojados de sus implicaciones más peligrosas, algunos de los planteos que habían sido formulados por la corriente posconciliar. ${ }^{59}$

Esa política integradora, que absorbía viejas demandas en el molde de una rígida ortodoxia doctrinaria que no dejaba ya lugar a aquellas "interpretaciones abusivas" a las que hiciera referencia monseñor Jorge Mejía, se vería favorecida en los últimos años del setenta por el creciente aislamiento político del régimen militar y por el notable giro que implicó para la Iglesia universal la llegada al pontificado de Juan Pablo II. En el ámbito de la Iglesia Latinoamericana, estos cambios se expresaron en la Conferencia de Puebla, que en sus conclusiones no sólo denunciaba enérgicamente la "doctrina de la seguridad nacional" y a los distintos regímenes dictatoriales que la aplicaban sino que ponía el énfasis en una pastoral que debía

59 Zanatta: Historia de la Iglesia... 
caracterizarse por su dinamismo, por su compromiso con los sectores populares y por un activo rol del laicado.

Poco a poco, y cuando aún no habían cicatrizado del todo las heridas que habían desgarrado a la Iglesia argentina a lo largo de casi quince años, la jerarquía comenzó a encontrar en el fomento de la religiosidad popular, en una adecuada actualización de la cuestión social y en el desarrollo de la pastoral en determinados ámbitos, como el de la juventud, herramientas eficaces para avanzar en la construcción de un nuevo proyecto hegemónico. ${ }^{60}$

Recibido el 17 de octubre de 2005 Aceptado el 15 de enero de 2006

60 Ezcurra, Ana María: Iglesia y Transición democrática. Ofensiva del neoconservadurismo católico en América Latina, Puntosur, Buenos Aires, 1988. 